\title{
Anti-diarrhoeal activity of ethanolic extract of heartwood of Pterocarpus marsupium roxb.
}

\author{
Bhawna Shridhar *, Munesh Mani, Prevesh Kumar, Shivansh Yadav, Kamal Kumar Mahaur \\ SPS, IFTM University, Moradabad 244002, U.P. India.
}

\begin{abstract}
Diarrhoea is a common cause of death in developing countries and second most common cause of infant's death worldwide. Pterocarpus marsupium is a medicinal herb belonging to the family Fabaceae has been traditionally used in the treatment of diarrhoea. They were found to contain tannins, alkaloids, saponins, sterols, triterpenes and reducing sugars. This study evaluated the antidiarrhoeal activity of ethanolic extract of heartwood of Pterocarpus marsupium induced by castor oil and magnesium sulphate in rat at 200 and 400 mg/kg b.w. The doses were given orally and showed significant antidiarrhoeal activity comparable with that of the standard drug loperamide. The statistical a nalyses of results were carried out using one-way analysis (ANOVA) followed by Student t-test. On the basis of these findings, it can be assumed that Pterocarpus marsupium could be a potential source for novel discovery for antidiarrhoeal. These results may support the fact that this plant is used traditionally to cure diarrhoea.
\end{abstract}

Keywords: Pterocarpus marsupium, Anti-Diarrhoeal, Castor Oil, Magnesium Sulphate, Loperamide

Article Info: Received 30 Oct 2018; Review Completed 10 Dec 2018; $\quad$ Accepted 12 Dec 2018; Available online 15 Dec 2018

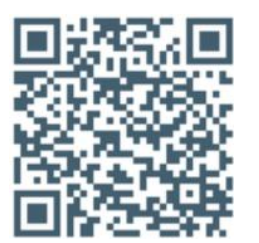

\section{Cite this article as:}

Shridhar B, Mani M, Kumar P, Yadav S, Mahaur KK, Anti-diarrhoeal activity of ethanolic extract of heartwood of Pterocarpus marsupium roxb., Journal of Drug Delivery and Therapeutics. 2018; 8(6-s):294-297

DOI: http://dx.doi.org/10.22270/jddt.v8i6-s.2140

Bhawna Shridhar, SPS, IFTM University, Moradabad 244002, U.P. India.

\section{INTRODUCTION}

Diarrhoea has long been recognized as one of the most important health problems in the developing countries and a major cause of infant mortality and morbidity [1-2]. Worldwide distribution of diarrhoea accounts for more than 5-8 million deaths each year in infants and small children less than 5 year. According to WHO estimation for the year 1998, there were about 7.1 million deaths due to diarrhoea[3]. Secretory diarrhoea is the most dangerous symptom of gastrointestinal problems ${ }^{[4]}$ and is associated with excessive defecation and stool outputs, the stools being of abnormally loose consistency[5]. So the present study was aimed to evaluate the traditional claim of antidiarrhoeal activity of ethanolic extract of heartwood of Pterocarpus marsupium in various experimental models.

\section{MATERIAL AND METHODS}

\section{Collection and Authentication of Plant Material:}

The heartwood of Pterocarpus marsupium Roxb. were obtained from Haridwar city and authenticated by Department of Botany, IFTM University, Moradabad, U.P. A voucher specimen was preserved in the Department of Pharmacy, IFTM University for future reference.

\section{Preparation of Extract:}

Heartwood of Pterocarpus marsupium washed with distilled water to remove dirt and soil and shade dried in a ventilated place at room temperature. The dried plant materials were reduced to coarse powder by mechanical grinder, extracted with $95 \%$ ethanol as solvent in soxhlet extractor for 18 hours. The ethanolic extract of heartwood of Pterocarpus marsupium was filtered and concentrated under reduce pressure using rotavapor (Buchi, USA), then freeze-dried (Freezone ${ }^{\circledR} 4.5$, Labconco, USA) and stored in deep freezer for further use. Solutions of the extracts were prepared freshly for each study.

\section{Preliminary Phytochemical Screening:}

The Ethanolic Extract of Pterocarpus marsupium (EEPM) was tested for the presence of various chemical constituents such as saponins, flavonoids, glycosides, alkaloids, tannins and reducing sugar.

\section{Pharmacological Studies :}

\section{Animals:}

Wistar albino rats of either sex weighing $200 \pm 25 \mathrm{~g}$ were kept in Departmental animal house at a temperature $(25 \pm 2)^{\circ} \mathrm{C}$ and 12 hours light/dark cycle respectively for one week before and during the experiments and fed with standard 
diet and water ad libitum. Animal studies were conducted according to the Institute Animal Ethics Committee. All the experiments were performed in the morning according to the current guidelines for the care of laboratory animals and the ethical guidelines for the investigation of experimental pain in conscious animals.

\section{Drugs and Chemicals:}

Magnesium sulphate, Loperamide (Ranbaxy (I) Ltd, Castor oil (Galaxo) and all other chemicals were of analytical grade.

\section{Acute Oral Toxicity Study (LD50):}

Acute oral toxicity studies were performed as per OECD-423 guidelines to determine the safety doses. Acute Oral Toxicity studies of the extract were carried out on female wistar strain albino rats. Rats were fasted over night and weight of each animal was recorded just before study. Animals were divided into ten groups. They were fed orally with the ethanolic extract of heartwood in increasing dose levels of $100,200,400,500,1000,1500,2000,3000,4000$ and 5000 $\mathrm{mg} / \mathrm{kg}$ b.w. through oral feeding needle. The animals were observed continuously for changes in signs and symptoms and mortality. The $\mathrm{LD}_{50}$ was $4 \mathrm{~g} / \mathrm{kg}$ body weight therefore the $\mathrm{ED}_{50}$ was found to be $400 \mathrm{mg} / \mathrm{kg}$ body weight. The doses for the study have been selected from these results and the experiments were carried out.

\section{Antidiarrhoeal Experiment Models:}

\section{Castor Oil-induced Diarrhoea:}

Wistar albino rats of either sex $(200 \pm 25 \mathrm{~g})$ were fasted for $24 \mathrm{~h}$ before starting the experiment. The animals were randomly housed in individual cages and divided into four groups $(\mathrm{n}=6)$. The group I received 1\% CMC (10 ml/kg p.o.) served as the control and group II received loperamide (3 $\mathrm{mg} / \mathrm{kg}$ ) acting as the standard. The last two groups received different doses (200 and $400 \mathrm{mg} / \mathrm{kg}$ p.o.) of the plant extract. One hour after the treatment, each animal received castor oil $(10 \mathrm{ml} / \mathrm{kg}$, p.o.) through a feeding needle. At 4 hours after dosing the castor oil, the individual rats cages were inspected for the presence of unformed water faecal pellets; their absence was recorded as a positive result, indicating protection from diarrhoea at that time ${ }^{[6-7]}$.

\section{Magnesium Sulphate-induced Diarrhoea:}

Animal divided in four group $(n=6)$ and diarrhoea were induced by oral administration of magnesium sulphate at the dose of $2 \mathrm{mg} / \mathrm{kg}$ b.w. to the animals, one hour after pre treatment with $1 \% \mathrm{CMC}(10 \mathrm{ml} / \mathrm{kg}$ p.o.) to the control group, loperamide $(3 \mathrm{mg} / \mathrm{kg}$ p.o.) to the standard group, and the plant extract at the doses of $200 \mathrm{mg} / \mathrm{kg}$ and $400 \mathrm{mg} / \mathrm{kg}$ to the remaining groups. During an observation period of 4 hours, the total number of faecal output and the number of diarrhoeic faeces excreted by the animals were recorded ${ }^{[8] \text {. }}$

\section{Statistical Analysis:}

The experimental results were expressed as the mean \pm standard error of the mean (S.E.M.). Data were evaluated by student's t-test and the means were compared using Graph pad prism 5 software t- test at $\mathrm{p}<0.001$.

\section{RESULTS}

\section{Phytochemical Analysis of Plant Extracts:}

The phytochemical analysis of heartwood of Pterocarpus marsupium $(95 \%$ ethanol extract) were revealed the presence of various chemical constituents such as alkaloids, saponins, glycosides, tannins, flavonoids, reducing sugar etc. (Table 1)

Table 1: Qualitative Analysis of Ethanolic Extract of Pterocarpus marsupium:

\begin{tabular}{|c|c|c|c|c|c|}
\hline S. No & $\begin{array}{c}\text { Phytochemical } \\
\text { Constituent }\end{array}$ & $\begin{array}{c}\text { Ethanolic } \\
\text { Extract }\end{array}$ & S. No & Phytochemical Constituent & $\begin{array}{c}\text { Ethanolic } \\
\text { Extract }\end{array}$ \\
\hline $\mathbf{1 .}$ & Carbohydrates & + & $\mathbf{8 .}$ & Proteins \& amino acids & - \\
\hline $\mathbf{2 .}$ & Alkaloids & + & $\mathbf{9 .}$ & Phenolic compounds & + \\
\hline $\mathbf{3 .}$ & Phytosterols & + & $\mathbf{1 0 .}$ & Tannins & + \\
\hline $\mathbf{4 .}$ & Fats \& oils & - & $\mathbf{1 1 .}$ & Flavonoids & + \\
\hline $\mathbf{5 .}$ & Gums \& mucilages & $\mathbf{+}$ & $\mathbf{1 2 .}$ & Triterpenes & - \\
\hline $\mathbf{6 .}$ & Saponins & + & $\mathbf{1 3 .}$ & Volatile oils & - \\
\hline $\mathbf{7 .}$ & Glycosides & + & $\mathbf{1 4 .}$ & Steroids \& triterpenoids & - \\
\hline
\end{tabular}

\section{Effect on Castor Oil-induced Diarrhoea:}

In the castor oil-induced diarrhoeal model in rat, the $95 \%$ ethanolic extract of Pterocarpus marsupium at the $200 \& 400$ $\mathrm{mg} / \mathrm{kg}$ dose levels were found to reduce the severity of diarrhoea in test animals. There was less significant effect with the dose of $200 \mathrm{mg} / \mathrm{kg}$ (p.o.) of the extract compared with control. The reduction on castor oil-induced diarrhoea at $400 \mathrm{mg} / \mathrm{kg}$ (p.o.) of plant extract treatment was found to be almost comparable with that of treatment by $3 \mathrm{mg} / \mathrm{kg}$ of loperamide (Table 2).

Table 2: Effect of Pterocarpus marsupium on castor oil induced diarrhoea in rats:

\begin{tabular}{|c|c|c|c|c|}
\hline Treatment & Dose (mg/kg) & $\begin{array}{c}\text { Total no of faeces in 4 } \\
\mathbf{h r}\end{array}$ & $\begin{array}{c}\text { Total no of wet faeces } \\
\text { in 4 hr }\end{array}$ & Reduction (\%) \\
\hline Control (1\%, $10 \mathrm{ml} / \mathrm{kg} \mathrm{CMC)}$ & $\ldots .$. & $13.66 \pm 0.01135$ & $10.63 \pm 0.003594$ & $\ldots .$. \\
\hline Loperamide & 3 & $2.466 \pm 0.1464^{* * *}$ & $1.431 \pm 0.0119^{* * *}$ & $86.53^{* * *}$ \\
\hline EEPM & 200 & $5.229 \pm 0.006436^{*}$ & $3.640 \pm 0.01072^{*}$ & $65.75^{*}$ \\
\hline EEPM & 400 & $2.764 \pm 0.2202^{* *}$ & $1.927 \pm 0.04667^{* *}$ & $81.87^{* *}$ \\
\hline
\end{tabular}

Values are mean \pm SEM $(\mathrm{n}=6)^{* * *} \mathrm{p}<0.001$ compared to control group. 


\section{Effect on magnesium sulphate-induced diarrhoea:}

In the magnesium sulphate-induced diarrhoeal model in rat, the $95 \%$ ethanolic extract of Pterocarpus marsupium at the $200 \& 400 \mathrm{mg} / \mathrm{kg}$ dose levels were found to reduce the severity of diarrhoea in test animals. There was less significant effect with the dose of $200 \mathrm{mg} / \mathrm{kg}$ (p.o.) of the extract compared with control. The reduction on magnesium sulphate -induced diarrhoea at $400 \mathrm{mg} / \mathrm{kg}$ (p.o.) of plant extract treatment was found to be almost comparable with that of treatment by $3 \mathrm{mg} / \mathrm{kg}$ of loperamide (Table 3).

Table 3: Effect of Pterocarpus marsupium on Magnesium Sulphate induced diarrhoea in rats:

\begin{tabular}{|c|c|c|c|c|}
\hline Treatment & $\begin{array}{c}\text { Dose } \\
\mathbf{( m g / k g )}\end{array}$ & $\begin{array}{c}\text { Total no of faeces in 4 } \\
\mathbf{h r}\end{array}$ & $\begin{array}{c}\text { Total no of wet } \\
\text { faeces in 4 hr }\end{array}$ & Reduction (\%) \\
\hline Control (1\%, 10ml/kg CMC) & $\ldots .$. & $11.15 \pm 0.1017$ & $10.65 \pm 0.009204$ & $\ldots \ldots$. \\
\hline Loperamide & 3 & $3.155 \pm 0.01206^{* * *}$ & $2.741 \pm 0.01177^{* * *}$ & $74.26^{* * *}$ \\
\hline EEPM & 200 & $6.278 \pm 0.1711^{*}$ & $4.943 \pm 0.01866^{*}$ & $53.58^{*}$ \\
\hline EEPM & 400 & $3.954 \pm 0.2115^{* *}$ & $3.035 \pm 0.03847^{* *}$ & $71.50^{* *}$ \\
\hline
\end{tabular}

Values are mean \pm SEM $(\mathrm{n}=6)^{* * *} \mathrm{p}<0.001$ compared to control group.

\section{DISCUSSION}

It is well know that the traditional uses of plants and their effects are due to the presence of secondary metabolites. These metabolites are alkaloids, glycosides, flavonoides, tannins, triterpenes etc. The medicinal value of plants depends on the presence of these metabolites qualitatively \& quantitatively. Number of factors, such as infective, immunological and nutritional has been involved in the perpetuation of the diarrhoeal syndrome[2]. Many plants conveniently available in India are used in traditional folklore medicine for the treatment of diarrhoea and dysentery 9 of the indigenous plants used Andrographis paniculata, Asparagus racemosus, Butea monosperma, Cassia auriculata, and others are mentioned ${ }^{10}$. Several studies have shown that prior administration with some plant extracts had a protective effect on the intestinal tract[11-13]. In the present study, the newer plant have used by tribens and rural have not been studied so far, was evaluated for its antidiarrhoeal potential against castor oil induced diarrhoea in Wistar albino rats. It is widely known that castor oil or its active component ricinoleic acid induces permeability changes in mucosal fluid and electrolyte transport that results in a hypersecretory response and diarrhoea. Ricinoleic acid markedly increased the PGE-2 content in the gut lumen and also caused on increases of the net secretion of the water and electrolytes into the small intestine. The liberation of ricinoleic acid from castor oil results in irritation and inflammation of the intestinal mucosa, leading to release of prostaglandins, which stimulate motility and secretion[14-15].The mechanism involved has been associated with dual effects on gastrointestinal motility as well as on water and electrolyte transport (decreasing $\mathrm{Na}+$ and $\mathrm{K}+$ absorption) across the intestinal mucosa[15]. These conditions tend to suggest that the extracts of Pterocarpus marsupium reduces diarrhoea by increasing reabsorption of electrolytes and water or by inhibiting induced intestinal accumulation of fluid just as loperamide. Loperamide acts by decreasing the transit velocity and increasing the capacity of the intestines to retain their fluids[16]. So the dose of 400 $\mathrm{mg} / \mathrm{kg}$ reduced diarrhoea by inhibiting castor oil induced intestinal accumulation of fluid. On the other hand, magnesium sulphate has been reported to induce diarrhoea by increasing the volume of intestinal content through prevention of reabsorption of water. It has also been demonstrated that it promotes the liberation of cholecystokinin from the duodenal mucosa, which increases the secretion and motility of small intestine and thereby prevents the reabsorption of sodium chloride and water [1718].The ethanolic extract was found to alleviate the diarrhoeic condition in this model. The Pterocarpus marsupium extract have increased the absorption of water and electrolyte from the gastrointestinal tract in rat as compared to the control. Previous reports have been demonstrated that the antidiarrhoeal activity of flavanoids[17], alkaloids[19], tannin[20], saponins, reducing sugars and sterols and/or terpenes[21] containing plant extracts. The phytochemical analysis of the extract showed the presence of alkaloids, saponins, sterols/or terpenes, tannins, mucilage and sugars. Therefore, these constituents might be responsible for the antidiarrhoeal activity of ethanolic extract of Pterocarpus marsupium. The results of the present study justify the traditional claims of Pterocarpus marsupium extract being an antidiarrhoeal drug. Moreover, the active constituents are responsible for the antidiarrhoeal activity remain to be identified.

\section{CONCLUSION}

The 95\% ethanolic extract of selected plant materials showed antidiarrhoeal activity in primarily evaluation of diarrhoeic conditions in test animals. The obtained results thus give the experimental basis to understand the use of selected traditional medicine, as an antidiarrhoeal agent. However, further bioassay guided phytochemical and pharmacological studies are required to identify the active principle(s) and exact mechanism(s) of action.

\section{ACKNOWLEDGEMENT}

The author wish to thank Dr. Sushil Kumar, Director, IFTM University, Moradabad for encouragement throughout the period of this research work. I would also like to give special thanks to my guide Mr. Kamal Kr. Mahaur for his inspiration \& providing necessary facilities to carry out this research work. I wholeheartedly thank to Mr. Shivansh Yadav for his everlasting support, immense love, encouragement and indispensable aid, without which this work is impossible. 


\section{REFERENCES}

1. Synder JD, Merson MH. The magnitude of the global problem of acute diarrhoea disease: A review of active surveillance of data. Bull WHO, 1982; 60:605-613.

2. Shoba FG, Thomas M. Study of antidiarrhoeal activity of four medicinal plants in castor oil induced diarrhoea. Journal of Ethnopharmacology. 2001; 76:73-76.

3. Park K. Park's. Text book of Preventive and Social Medicine. Banarsidas Bharat Publishers, Jabalpur, 2000.

4. Fontaine 0. Diarrhoea and treatment. Lancet, 1988; 28:12341235.

5. Aranda MJ, Gianella, RA, Acute diarrhoea: A practical review. Am. J Med. 1999; 106:670-676.

6. Amresh, Reddy GD, Rao ChV, Shirwarikar A. Ethnomedical value of Cissampelos pareira extract in experimentally induced diarrhoea, Acta Pharm. 2004; 54:27-35.

7. Uddin SJ, Shilpi JA, Alam SMS, Alamgir M, Rahman MT, Sarker SD. Antidiarrhoeal activity of the methanol extract of the barks of Xylocarpus moluccensis in castor oil and magnesium sulphate-induced diarrhoea models in mice. Journal of Ethnopharmacology. 2005; 101:139- 143.

8. Adeyemi 00, Akindele AJ. Antidiarrhoeal activity of the ethyl acetate extract of Baphia nitida (Papilionaceae), Journal of Ethnopharmacology. 2008; 116:407-412.

9. Dash SK, Padhy S. Review on Ethnomedicines for Diarrhoea Diseases from Orissa: Prevalence versus Culture. J Hum Ecol. 2006; 20(1):59-64.

10. Chopra RN, Nayar SL, Chopra IC. Glossary of Indian Medicinal Plants. Council of Scientific and Industrial Research, New Delhi, 1956, 255-257.

11. Rani S, Ahamed N, Rajaram S, Saluja R, Thenmozhi S, Murugesan T. Antidiarrhoeal evaluation of Clerodendrum phlomidis Linn. leaf extract in rats. J Ethanopharmacol. 1999; 68:315-319.

12. Majumdar AM, Upadhye AS, Misar AV. Studies on antidiarrhoeal activity of Jatropha curcus root extract in albino mice. J Ethanopharmacol. 2000; 70:183-187.
13. Kumar S, Dewan S, Sangraula H, Kumar VL. Anti- diarrhoeal activity of the latex of Calotropis procera. J Ethanopharmacol. 2001; 76:115-118.

14. Venkatesan N, Vadivu T, Sathiya N, Arokya A, Sundararajan R, Sengodan G et al. Anti-diarrhoeal potential of Asparagus racemosus wild root extracts in laboratory animals. J Pharm Pharmaceut Sci. 2005; 8(1):39-45.

15. Rouf AS, Islam MS, Rahman MT. Evaluation of antidiarrhoeal activity of Rumex maritimus roots. Journal of Ethnopharmacology. 2003; 84:307-310.

16. Vareinshang T, Yadav AK. Antidiarrhoeal activity of Rhus javanica ripens fruit extract in albino mice. Fitoterapia. 2004; 75:39-44.

17. Galvez A, Zarzuelo ME, Crespo MD, Lorente M, Ocete A, Jimenez J. Antidiarrhoeic activity of Euphorbia chirta extract and isolation of active flavonoid constituent. Planta Medica. 1993; 59:333-336.

18. Zavala MA, Perez S, Perez C, Vargas R, Perez RM. Antidiarrhoeal activity of Waltheria Americana, Commelina coelestis and Alternanthera repens. Journal of Ethnopharmacology. 1998; 61:41-47.

19. Gricilda SF, Thomas M. Study of antidiarrhoeal activity of four medicinal plants in castor oil-induced diarrhoea. J Ethnopharmacol. 2001; 76:73-76.

20. Mukherjee PK, Saha K, Murugesan T, Mandal SC, Pal M, Saha BP. Screening of anti-diarrhoeal profile of some plant extracts of a specific region of West Bengal, India. J Ethnopharmacol. 1998; 60:85-89.

21. Otshudi AL, Vercruysse A, Foriers A. Contribution to the Ethanobotanical, Phytochemical and Pharmacological studies of traditionally used medicinal plants in the treatment of dysentery and diarrhoea in Lomela area (DRC). J Ethnopharmacol. 2000; 71:411-423. 